\title{
The influence of seed coating on the vigor and early seedling growth of barley
}

\author{
Francisco M.F. Corlett ${ }^{1}$, Cassyo de A. Rufino 2 , Jucilayne F. Vieira ${ }^{2}$, Lizandro \\ C. Tavares ${ }^{2}$, Lilian V.M. Tunes ${ }^{2}$, and Antonio C.S.A. Barros ${ }^{2}$ \\ ${ }^{1}$ Federal Institute of Rio Grande do Sul-IFSUL. General Osório 348, Centro, 95700-000, Pelotas, Rio \\ Grande do Sul, Brazil. \\ ${ }^{2}$ Federal University of Pelotas, Post Graduate Course in Seed Science and Technology. 96 001-970, Pelotas, \\ Rio Grande do Sul, Brazil.
}

\begin{abstract}
F.M.F. Corlett, C.A. Rufino, J.F. Vieira, L.C. Tavares, L.M. Tunes and A.C.S.A. Barros. The influence of seed coating on the vigor and early seedling growth of barley. Cien. Inv. Agr. 41(1): 129-136. Seed coating is a process in which a thin and uniform polymer layer is deposited on the surface of a seed. The objective of this study was to evaluate the vigor of barley seed coated with a commercial polymer and various combinations of calcium, silicon and fungicide. In addition to a control with only the polymer coating, a total of 17 seed coating treatments were used in a completely randomized factorial design ( 18 treatments $\times 4$ replicates per treatment). Calcium and silicon were applied at concentrations of 0,25 or $50 \mathrm{~g} \mathrm{~kg}^{-1}$ of seed, and 0 or $3.0 \mathrm{~mL}$ of fungicide was applied. The means were compared using a Duncan test $(\mathrm{P} \leq 0.05)$. The results showed that a coating of polymer, fungicide, calcium and silicon did not affect the physiological quality of the barley seed and that the use of these products can protect the seed against pathogens without affecting the rate of emergence of the barley seedlings while ensuring good seed appearance, adhesion, distribution and coloration.
\end{abstract}

Key words: seed protection, physiological quality, seed quality.

\section{Introduction}

The process of seed coating involves the application of finely ground solids or liquids containing dissolved or suspended solids to form a more or less continuous layer covering the natural seed coat (Scott, 1989). Because the coatings are extremely thin, multiple coatings of various ingredients are also possible (John et al., 2005). Seed coating is

Received April 10, 2013. Accepted February 25, 2014 Corresponding author: cassyo.araujo@yahoo.com.br used in conjunction with chemical and biological treatments. The protective material is applied in very precise amounts and with a minimal impact on the environment (Baudet and Peres, 2004).

Seed coating has long been used, especially for the seeds of vegetables, forest plants and ornamentals. It can be employed to increase seed size, to improve seed shape and texture and to facilitate direct sowing. This advanced technology allows the application of combinations of nutrients, fungicides, insecticides, 
herbicides and beneficial microorganisms to seed (Nascimento et al., 1993). In addition, it serves to reduce the exposure of agricultural workers to pesticides and improves the contact between seeds and the soil, contributing to the preservation of the environment (Baudet and Peres, 2004; Levien et al., 2008). The seed coating should be more or less continuous to eliminate or minimize product dustoff, as low dust-off is an important factor in worker safety (Taylor et al., 2001). Polymer materials are slightly more viscous than most chemicals used as pesticides in seed treatment. Consequently, the application of these polymers requires a machine that can apply the coating with high precision. The treatment of seed with various combinations of polymers, fungicides and insecticides requires only a small financial investment for the farmer but promises an excellent return on this investment. To guarantee that all seeds are coated with an adequate quantity of the chemical product and thereby maximize the potential benefit from the seed treatment, efficient application is essential (Levien et al., 2008). Several previous studies have reported satisfactory effects of seed coating on seed germination, seedling growth, root and shoot growth, leaf area, dry biomass and increase in yield (Zelonka et al., 2005; Gevrek et al., 2012; Tavares et al., 2012; Tavares et al., 2013). In addition, seed coating improves plantability, reduces the percentage of skips and doubles, reduces the formation of dust from seed and minimizes the leaching of insecticide from treated seed (Avelar et al., 2012). Accordingly, the objective of this study was to evaluate the effect on the seed quality and seedling performance of barley resulting from seed coating with various combinations of calcium, silicon, polymer and fungicide.

\section{Materials and methods}

This study was performed at the Laboratory of Seed Analysis, LDAS, and Faculty of Agronomy Eliseu Maciel at the Federal University of Pelotas. Seed of the barley cultivar Scarlett (2008/2009 season) were supplied by the Company Wester- mann, located in the city of Pelotas, in the State of Rio Grande do Sul, Brazil.

In this study, barley seeds were coated with various combinations (Table 1) of the following products: fludioxinil + metalaxyl-M $\left(25 \mathrm{~g} \mathrm{~L}^{-1}+10 \mathrm{~g} \mathrm{~L}^{-1}\right)$,

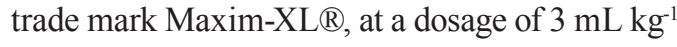
of seed; dolomitic limestone $\left(0,25\right.$ and $50 \mathrm{~g} \mathrm{~kg}^{-1}$ of seed); and aluminum silicate $\left(0,25\right.$ and $50 \mathrm{~g} \mathrm{~kg}^{-1}$ of seed). All seed treatments also included $2 \mathrm{~mL}$ CF Clear ${ }^{\circledR}$ polymer and $4 \mathrm{~mL}$ of dye (red). Lastly, $15 \mathrm{~mL}$ of water kg-1 of seed was added to obtain a concentration of dolomitic limestone or aluminum silicate of $25 \mathrm{~g} \mathrm{~kg}^{-1}$ of seed, whereas $25 \mathrm{~mL}$ of water $\mathrm{kg}^{-1}$ of seed was added to obtain a concentration of $50 \mathrm{~g} \mathrm{~kg}^{-1}$ of seed. The volume of solution derived from the mixture of solid ingredients (calcium and silicon compounds) and liquid ingredients (fungicide, polymer, dye and water) was $24 \mathrm{~mL} \mathrm{~kg}^{-1}$ of seed and $34 \mathrm{~mL} \mathrm{~kg}^{-1}$ of seed, respectively. The treatments and dosages used are shown in Table 1.

Table 1. Description of the treatments evaluated.

\begin{tabular}{|c|c|}
\hline Treatments & Dosages \\
\hline $\mathrm{T} 1$ & $\mathrm{Ca}(25 \mathrm{~g})$ \\
\hline $\mathrm{T} 2$ & $\mathrm{Si}(25 \mathrm{~g})$ \\
\hline $\mathrm{T} 3$ & $\mathrm{Ca}(25 \mathrm{~g})+\mathrm{Si}(25 \mathrm{~g})$ \\
\hline $\mathrm{T} 4$ & Fungicide (25 g) \\
\hline $\mathrm{T} 5$ & Fungicide $+\mathrm{Ca}(25 \mathrm{~g})$ \\
\hline $\mathrm{T} 6$ & Fungicide $+\mathrm{Si}(25 \mathrm{~g})$ \\
\hline $\mathrm{T} 7$ & Fungicide $+\mathrm{Si}(25 \mathrm{~g})+\mathrm{Ca}(25 \mathrm{~g})$ \\
\hline $\mathrm{T} 8$ & $\mathrm{Ca}(50 \mathrm{~g})$ \\
\hline T9 & $\mathrm{Si}(50 \mathrm{~g})$ \\
\hline $\mathrm{T} 10$ & $\mathrm{Ca}(25 \mathrm{~g})+\mathrm{Si}(50 \mathrm{~g})$ \\
\hline $\mathrm{T} 11$ & $\mathrm{Ca}(50 \mathrm{~g})+\mathrm{Si}(25 \mathrm{~g})$ \\
\hline $\mathrm{T} 12$ & Fungicide $+\mathrm{Ca}(50 \mathrm{~g})$ \\
\hline $\mathrm{T} 13$ & Fungicide $+\mathrm{Si}(50 \mathrm{~g})$ \\
\hline $\mathrm{T} 14$ & Fungicide $+\mathrm{Si}(50 \mathrm{~g})+\mathrm{Ca}(25 \mathrm{~g})$ \\
\hline $\mathrm{T} 15$ & Fungicide $+\mathrm{Si}(25 \mathrm{~g})+\mathrm{Ca}(50 \mathrm{~g})$ \\
\hline $\mathrm{T} 16$ & Fungicide $+\mathrm{Si}(50 \mathrm{~g})+\mathrm{Ca}(50 \mathrm{~g})$ \\
\hline $\mathrm{T} 17$ & $\mathrm{Ca}(50 \mathrm{~g})+\mathrm{Si}(50 \mathrm{~g})$ \\
\hline $\mathrm{T} 18$ & Uncoated control \\
\hline
\end{tabular}


The source of the silicon used was aluminum silicate in the form of a whitish non-toxic dust obtained from ground rock and containing $77.9 \%$ $\mathrm{SiO}_{2}, 23.73 \% \mathrm{Al}_{2} \mathrm{O}_{3}, 0.23 \% \mathrm{CaO}$ and $0.36 \% \mathrm{~K}_{2} \mathrm{O}$. The source of $\mathrm{Ca}$ was dolomitic limestone containing calcium oxide $(\mathrm{CaO})$ and magnesium oxide $(\mathrm{MgO})$ with a Relative Power of Total Neutralization (RPTN) of $75 \%$ and a reactivity of $77 \%$.

To coat the seed, the products were applied manually to $0.5 \mathrm{~kg}$ of seed in the following order: fungicide + polymer + calcium and silicon. The seed was placed in plastic bags and then agitated until all seeds were completely covered (approximately 5 minutes). The treated seed was then naturally dried for $48 \mathrm{~h}$.

Sowing was conducted on August 29, 2009 in plots measuring $10 \mathrm{~m} \times 1 \mathrm{~m}$ in Albaqualf soil under conventional tillage. Each experimental plot consisted of four rows $1 \mathrm{~m}$ long with $0.10 \mathrm{~m}$ spacing between rows and 50 seeds planted per line. Irrigation was performed daily for a period of 30 days. No other management practices were necessary. The number of emerged seedlings was counted daily until it reached a constant level (a period of 21 days). For each replication, the emergence speed index was calculated by summing the daily ratios of the number of emerged plants to the number of days from sowing (Maguire, 1962) using the following formula:

$$
\mathrm{ESI}=\frac{\mathrm{E} 1}{\mathrm{~N} 1}+\frac{\mathrm{E} 2}{\mathrm{~N} 2}+\ldots+\frac{\mathrm{En}}{\mathrm{Nn}},
$$

where ESI = emergence speed index; E1, E2, $\mathrm{En}=$ number of seedlings emerged, computed at the first, second and last counts; N1, N2, Nn = number of days from sowing to the first, second and final counts.

For the determination of leaf area and dry biomass, 10 seedlings were collected weekly; they were cut at ground level on the 10th, 20th and 30th days after emergence (DAE). Measurements of leaf area were performed using a photoelectric device (LI-
3100 Area Meter, LI-COR Ltda.) giving a direct reading in $\mathrm{cm}^{2}$. The seedlings were oven dried at $65^{\circ} \mathrm{C}$ for 72 hours to obtain the dry biomass. A Burris (s.d.) scale with scores ranging from 0 to 10 was used to evaluate the visual quality of the treated seed. Four replicate subsamples, each containing $500 \mathrm{~g}$ of seeds, were used per treatment.

A completely randomized factorial design (18 treatments $\times 4$ replicates per treatment) was used. The study data were analyzed with the ASSISTAT statistical program, version 7.5 (Silva and Azevedo, 2009). The treatment effects were compared using a Duncan test at a 5\% significance level.

\section{Results and discussion}

Almost all treatment groups showed an emergence speed index greater than that of the control (Figure 1). Only T9 (50 g Si) was statistically similar to the control treatment. Treatments T1, T5, T7, T8, T13, T14 and T16, which contained (1) fungicide and silicon, (2) calcium applied alone or in combination with fungicide (3), stimulated the rapid growth of barley seedlings, offering the greatest potential for initial vigor. Zorato et al. (2001) have shown that seed treatment with fungicide can control important seed-transmitted pathogens. For this reason, the treatment of seed with fungicide is important because it can guarantee adequate populations of plants if the weather and soil conditions are unfavorable. In addition, silicon is an important amendment because it positively influences plant growth and development (Tavares et al., 2012). Tavares et al. (2012) observed that a coating containing a silicon source did not affect either the germination of the coated rice seed or the emergence of seedlings from the coated seed in the field; these same authors also observed that a coating of aluminum silicate applied to rice seed promoted a greater leaf area on the plants at 20 days after emergence. In addition, their study showed that dolomitic limestone and aluminum silicate, applied in a seed coating either alone or 
in combination, produced plants with a higher dry biomass as early as 20 days after emergence.

The values obtained in this study (Table 2 ) showed that treatments $\mathrm{T} 5$ (fungicide $+25 \mathrm{~g} \mathrm{Ca}$ ) and $\mathrm{T} 13$ (fungicide $+50 \mathrm{~g} \mathrm{Si}$ ) showed strong and significant effects on the leaf area of the barley seedlings on the 10th, 20th and 30th DAE. At 10 days after emergence, the effects on the seedling leaf area of treatments T2, T4, T7, T8, T10, T11, T13 and T14 do not differ; however, all of these effects on leaf area were higher than the value found for the control treatment. Tavares et al. (2012) found that treatments of the rice cultivar IRGA $422 \mathrm{CL}$ with dolomitic limestone and aluminum silicate, either alone or in combination, showed significantly greater values of leaf area than the control treatment. In the current study, only treatments T5 and T13 showed significantly greater values of leaf area than the other treatments at 20 days after emergence. Moreover, no statistically significant differences were found among the effects of treatments T2, T3, T5, T9 and T13 on leaf area at 30 days after emergence.

In general, the seed coating influenced the rate of seedling emergence, as shown by the results for

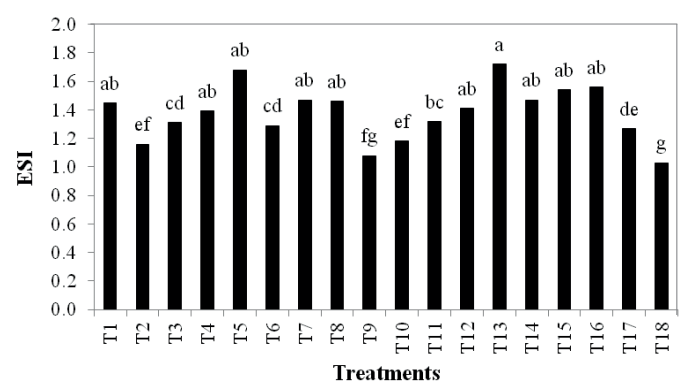

Figure 1. Emergence speed index (ESI) of barley seed treated with various doses of calcium and silicon, with and without fungicide. Means followed by the same letter in the same column are not significantly different (Duncan test, 5\% significance level). T1: Ca (25 g); T2: Si (25 g); T3: Ca $(25 \mathrm{~g})+\mathrm{Si}(25 \mathrm{~g})$; T4: Fung (25 g); T5: Fung + Ca (25 g); T6: Fung + Si (25 g); T7: Fung + Si (25 g) + Ca (25 g); T8: Ca $(50 \mathrm{~g})$; T9: $\mathrm{Si}(50 \mathrm{~g})$; T10: Ca (25 g) + Si (50 g); T11: Ca (50 g) + Si (25 g); T12: Fung + Ca (50 g); T13: Fung + Si (50 g); T14: Fung + Si (50 g) + Ca (25 g); T15: Fung + Si (25 g) + $\mathrm{Ca}(50 \mathrm{~g})$; T16: Fung + Si $(50 \mathrm{~g})+\mathrm{Ca}(50 \mathrm{~g}) ; \mathrm{T} 17: \mathrm{Ca}(50 \mathrm{~g})$ + Si (50 g); T18: Control. the emergence speed index (Figure 1). According to Tavares et al. (2012), the coating of lowland rice seed with dolomitic limestone and aluminum silicate did not negatively affect the physiological quality of the seed. In contrast, the treatments produced increments in the initial growth of seedlings relative to the control treatment.

The production of dry biomass by the barley plants is shown in Table 3. Treatments T5 (fungicide and calcium) and T13 (fungicide and silicon) produced a strong and consistent performance for all three evaluation periods. Tavares et al. (2012) have also found that the dry weight of rice plants grown from seed coated with dolomitic limestone and aluminum silicate, either alone or in combination, was significantly greater than the value for the control treatment.

These results document the advantages of seed coating; however, certain authors have stated that coating can negatively affect the physiological quality of seed. Franzin et al. (2004) found that germination of lettuce seed was inhibited after coating. Silva and Nakagawa (1998) found that coated seed showed a 20 days delay in germination. Accordingly, small differences in vigor can contribute to the uneven characteristics of the initial population of plants. However, seedlings that have overcome the barrier produced by the coating show equal growth rates. Moreover, both in the laboratory and under natural conditions, the seedlings are uniform in both fresh and dry weight.

From an analysis of methods of production and production technologies such as seed coating, Baudet and Peres (2004) concluded that seed must show a good aggregate value in an increasingly competitive market. Seed that has a high uniformity of germination and emergence and that produces seedlings with a high growth potential are needed for this purpose. The use of artificial materials as seed coatings can help to identify a set of characteristics necessary for the establishment of seedlings. This approach can serve to standardize the early stages 
Table 2. Leaf area of barley seedlings grown from seed coated with various doses of calcium and silicon, with and without fungicide, at different times of evaluation. Capão do Leão - RS.

\begin{tabular}{|c|c|c|c|c|}
\hline & & \multicolumn{3}{|c|}{ Times of evaluation } \\
\hline & & $10 \mathrm{DAE}^{1}$ & $20 \mathrm{DAE}$ & 30 DAE (days) \\
\hline \multicolumn{2}{|c|}{ Treatments } & \multicolumn{3}{|c|}{ Leaf area $\left(\mathrm{cm}^{-2} \mathrm{pl}^{-1}\right)$} \\
\hline T1 & $\mathrm{Ca}(25 \mathrm{~g})$ & $26.60 \mathrm{~cd}$ & $78.63 \mathrm{~cd}$ & $120.16 \mathrm{gh}$ \\
\hline $\mathrm{T} 2$ & $\mathrm{Si}(25 \mathrm{~g})$ & $29.37 \mathrm{ab}$ & $70.01 \mathrm{fg}$ & $172.33 \mathrm{ab}$ \\
\hline $\mathrm{T} 3$ & $\mathrm{Ca}(25 \mathrm{~g})+\mathrm{Si}(25 \mathrm{~g})$ & $21.21 \mathrm{f}$ & $62.12 \mathrm{~h}$ & $164.70 \mathrm{ab}$ \\
\hline $\mathrm{T} 4$ & Fung $(25 \mathrm{~g})$ & $30.68 \mathrm{ab}$ & 72.94 ef & $123.66 \mathrm{gh}$ \\
\hline $\mathrm{T} 5$ & Fung $+\mathrm{Ca}(25 \mathrm{~g})$ & $33.76 \mathrm{a}^{2}$ & 99.98 a & $188.65 \mathrm{a}$ \\
\hline T6 & Fung $+\mathrm{Si}(25 \mathrm{~g})$ & $25.10 \mathrm{de}$ & $55.92 \mathrm{i}$ & $136.55 \mathrm{fg}$ \\
\hline $\mathrm{T} 7$ & Fung $+\mathrm{Si}(25 \mathrm{~g})+\mathrm{Ca}(25 \mathrm{~g})$ & $29.20 \mathrm{ab}$ & $67.53 \mathrm{gh}$ & $159.87 \mathrm{bc}$ \\
\hline $\mathrm{T} 8$ & $\mathrm{Ca}(50 \mathrm{~g})$ & $29.87 \mathrm{ab}$ & $72.94 \mathrm{ef}$ & $136.15 \mathrm{fg}$ \\
\hline T9 & $\mathrm{Si}(50 \mathrm{~g})$ & $27.00 \mathrm{~cd}$ & $80.13 \mathrm{~cd}$ & $183.11 \mathrm{ab}$ \\
\hline $\mathrm{T} 10$ & $\mathrm{Ca}(25 \mathrm{~g})+\mathrm{Si}(50 \mathrm{~g})$ & $28.44 \mathrm{ab}$ & 74.80 de & 138.18 ef \\
\hline $\mathrm{T} 11$ & $\mathrm{Ca}(50 \mathrm{~g})+\mathrm{Si}(25 \mathrm{~g})$ & $30.06 \mathrm{ab}$ & $66.23 \mathrm{gh}$ & $156.47 \mathrm{~cd}$ \\
\hline $\mathrm{T} 12$ & Fung $+\mathrm{Ca}(50 \mathrm{~g})$ & $27.36 \mathrm{bc}$ & $67.52 \mathrm{gh}$ & $119.37 \mathrm{gh}$ \\
\hline $\mathrm{T} 13$ & Fung $+\mathrm{Si}(50 \mathrm{~g})$ & $32.58 \mathrm{ab}$ & $104.74 \mathrm{a}$ & $183.24 \mathrm{a}$ \\
\hline T14 & Fung $+\mathrm{Si}(50 \mathrm{~g})+\mathrm{Ca}(25 \mathrm{~g})$ & $30.55 \mathrm{ab}$ & 76.62 de & 138.06 ef \\
\hline T15 & Fung $+\mathrm{Si}(25 \mathrm{~g})+\mathrm{Ca}(50 \mathrm{~g})$ & $28.15 \mathrm{bc}$ & $83.16 \mathrm{c}$ & $173.66 \mathrm{ab}$ \\
\hline T16 & Fung $+\mathrm{Si}(50 \mathrm{~g})+\mathrm{Ca}(50 \mathrm{~g})$ & $25.24 \mathrm{~cd}$ & $65.98 \mathrm{gh}$ & $141.36 \mathrm{de}$ \\
\hline $\mathrm{T} 17$ & $\mathrm{Ca}(50 \mathrm{~g})+\mathrm{Si}(50 \mathrm{~g})$ & $21.79 \mathrm{ef}$ & $57.12 \mathrm{i}$ & $162.34 \mathrm{bc}$ \\
\hline $\mathrm{T} 18$ & Control & $21.03 \mathrm{f}$ & $38.88 \mathrm{j}$ & $114.712 \mathrm{~h}$ \\
\hline
\end{tabular}

${ }^{1}$ DAE: days after emergence. ${ }^{2}$ Means followed by the same letter in the same column are not significantly different (Duncan test, $5 \%$ significance level).

Table 3. Dry matter production of barley plants grown from seed coated with various doses of calcium and silicon, with and without fungicide, at different times of evaluation. Capão do Leão - RS.

\begin{tabular}{|c|c|c|c|c|}
\hline & & \multicolumn{3}{|c|}{ Times of evaluation } \\
\hline & & $10 \mathrm{DAE}^{1}$ & $20 \mathrm{DAE}$ & 30 DAE (days) \\
\hline \multicolumn{2}{|c|}{ Treatments } & \multicolumn{3}{|c|}{ Dry matter $\left(\mathrm{mg} \mathrm{pl}^{-1}\right)$} \\
\hline $\mathrm{T} 1$ & $\mathrm{Ca}(25 \mathrm{~g})$ & $0.102 \mathrm{bc}$ & $0.310 \mathrm{de}$ & $0.541 \mathrm{f}$ \\
\hline $\mathrm{T} 2$ & $\mathrm{Si}(25 \mathrm{~g})$ & $0.116 \mathrm{ab}$ & $0.345 \mathrm{~cd}$ & $0.780 \mathrm{ab}$ \\
\hline $\mathrm{T} 3$ & $\mathrm{Ca}(25 \mathrm{~g})+\mathrm{Si}(25 \mathrm{~g})$ & $0.098 \mathrm{bc}$ & $0.279 \mathrm{fg}$ & $0.671 \mathrm{~cd}$ \\
\hline $\mathrm{T} 4$ & Fung $(25 \mathrm{~g})$ & $0.102 \mathrm{bc}$ & $0.315 \mathrm{de}$ & $0.561 \mathrm{f}$ \\
\hline T5 & Fung $+\mathrm{Ca}(25 \mathrm{~g})$ & $0.139 \mathrm{a}^{2}$ & $0.412 \mathrm{ab}$ & $0.843 \mathrm{a}$ \\
\hline T6 & Fung $+\mathrm{Si}(25 \mathrm{~g})$ & $0.091 \mathrm{c}$ & $0.389 \mathrm{ab}$ & $0.706 \mathrm{bc}$ \\
\hline $\mathrm{T} 7$ & Fung $+\mathrm{Si}(25 \mathrm{~g})+\mathrm{Ca}(25 \mathrm{~g})$ & $0.107 \mathrm{ab}$ & $0.334 \mathrm{~cd}$ & $0.639 \mathrm{de}$ \\
\hline $\mathrm{T} 8$ & $\mathrm{Ca}(50 \mathrm{~g})$ & $0.103 \mathrm{bc}$ & $0.304 \mathrm{ef}$ & $0.567 \mathrm{f}$ \\
\hline T9 & $\mathrm{Si}(50 \mathrm{~g})$ & $0.111 \mathrm{ab}$ & $0.341 \mathrm{~cd}$ & $0.763 \mathrm{ab}$ \\
\hline $\mathrm{T} 10$ & $\mathrm{Ca}(25 \mathrm{~g})+\mathrm{Si}(50 \mathrm{~g})$ & $0.101 \mathrm{bc}$ & $0.323 \mathrm{de}$ & $0.659 \mathrm{~cd}$ \\
\hline T11 & $\mathrm{Ca}(50 \mathrm{~g})+\mathrm{Si}(25 \mathrm{~g})$ & $0.110 \mathrm{ab}$ & $0.351 \mathrm{~cd}$ & $0.779 \mathrm{ab}$ \\
\hline $\mathrm{T} 12$ & Fung $+\mathrm{Ca}(50 \mathrm{~g})$ & $0.097 \mathrm{bc}$ & $0.370 \mathrm{bc}$ & $0.639 \mathrm{de}$ \\
\hline $\mathrm{T} 13$ & Fung $+\mathrm{Si}(50 \mathrm{~g})$ & $0.142 \mathrm{a}$ & $0.438 \mathrm{a}$ & $0.844 \mathrm{a}$ \\
\hline $\mathrm{T} 14$ & Fung $+\mathrm{Si}(50 \mathrm{~g})+\mathrm{Ca}(25 \mathrm{~g})$ & $0.107 \mathrm{ab}$ & $0.279 \mathrm{fg}$ & $0.738 \mathrm{ab}$ \\
\hline $\mathrm{T} 15$ & Fung $+\mathrm{Si}(25 \mathrm{~g})+\mathrm{Ca}(50 \mathrm{~g})$ & $0.095 \mathrm{bc}$ & $0.317 \mathrm{de}$ & $0.741 \mathrm{ab}$ \\
\hline T16 & Fung $+\mathrm{Si}(50 \mathrm{~g})+\mathrm{Ca}(50 \mathrm{~g})$ & $0.114 \mathrm{ab}$ & $0.323 \mathrm{de}$ & $0.706 \mathrm{bc}$ \\
\hline $\mathrm{T} 17$ & $\mathrm{Ca}(50 \mathrm{~g})+\mathrm{Si}(50 \mathrm{~g})$ & $0.094 \mathrm{c}$ & $0.272 \mathrm{~g}$ & 0.608 ef \\
\hline $\mathrm{T} 18$ & Control & $0.064 \mathrm{~d}$ & $0.185 \mathrm{~h}$ & $0.317 \mathrm{~g}$ \\
\hline
\end{tabular}

${ }^{1}$ DAE: days after emergence. ${ }^{2}$ Means followed by the same letter in the same column are not significantly different (Duncan test, $5 \%$ significance level). 
of the plant for seed production. Studies on barley seed coating have been conducted by Pilar et al. (2009); Pilar-Izquiedo et al. (2012), and Gorim and Asch (2012). However, more information is needed about the effects that these coatings may have on germination and early seedling growth.

An important finding of the current study is that the coated seed showed variation from 9.0 to 10.0 on Burris' scale. This result showed that the treatments produced excellent coverage, an attractive appearance, good adherence and coloration and a desirable distribution of the products used to coat the seed.

The coating of barley seed with calcium, silicon, polymer and fungicide did not affect the emergence rate. Indeed, the coatings increased the initial growth of seedlings relative to the control. The combinations of fungicide with $25 \mathrm{~g}$ of a calcium source and fungicide with $50 \mathrm{~g}$ of a silicon source (expressed in units of $\mathrm{g} \mathrm{kg}^{-1}$ of seed) promotes seedling vigor, and the vigor of the seedlings grown from the coated seed was found to be higher than that of the seedlings grown from the control seed. Seed coated with calcium, silicon, polymer and fungicide produced seedlings with a greater leaf area than that of the seedlings grown from the control seed. Barley seed coated with calcium, silicon, polymer and fungicide is desirable in terms of appearance, adhesion, distribution and coloration.

\section{Resumen}

F.M.F. Corlett, C.A. Rufino, J.F. Vieira, L.C. Tavares, L.M. Tunes y A.C.S.A. Barros. Influencia del recubrimiento de semillas en el vigor y crecimiento temprano de las plántulas de cebada. Cien. Inv. Agr. 41(1): 129-136. El recubrimiento de semillas consiste en la deposición de una capa delgada y uniforme de un polímero sobre la superficie de la semilla. El objetivo de este estudio fue evaluar el vigor de las semillas de cebada, revestido con calcio y silicio, polímero comercial y fungicida. Los tratamientos consistieron de dos concentraciones de calcio y silicio para el revestimiento de las semillas, con niveles de $0,25 \mathrm{y}$ $50 \mathrm{~g} \mathrm{~kg}^{-1}$ semilla. Se utilizó $3,0 \mathrm{~mL}$ de fungicida y un total de 17 tratamientos y un control, sin ningún tratamiento. El diseño experimental fue completamente al azar en un esquema factorial $(18 \times 4)$ y los resultados fueron analizados a través de la comparación de medias, utilizando la prueba de Duncan $(\mathrm{P} \leq 0,05)$. Los resultados mostraron que las semillas de cebada recubiertas con fungicida, calcio y silicio, no se vieron afectadas en su calidad fisiológica y, posiblemente, el uso de estos productos protege la semilla contra patógenos, sin afectar su velocidad de aparición, y proporcionan semillas con buena apariencia, adherencia, distribución y coloración.

Palabras clave: Calidad fisiológica de semillas, calidad de semillas, protección.

\section{References}

Avelar, S.A.G., F.V.S, G. Fiss, L. Baudet, and S.T. Peske. 2012. The use of film coating on the performance of treated corn seed. Revista Brasileira de Sementes 34:186-192.

Baudet, L.M., and W. Peres. 2004. Seed coating. Seed News 8:20-23.
Franzin, S.M., N.L. Menezes, D.C. Garcia, and T. Rovers. 2004. Assessment of vigor in simple and pelletized lettuce seeds. Revista Brasileira de Sementes 26:114-118.

Gevrek, M.N., G.D. Atasoy, and A. Yigit. 2012. Growth and yield response of rice (Oryza sativa L.) to different seed coating agents. Int. J. Agric. Biol. 14:826-830. 
Gorim, L., and F. Asch. 2012. Effects of composition and share of seed coatings on the mobilization efficiency of cereal seeds during germination. J. Agronomy \& Crop Science 198:81-91.

John, S., A. Bharathi, P. Natesan, and K. Raja. 2005. Effect of polymer coating on germination and seedling vigour in maize cv. Co 1. Karnataka J. Agric. Sci. 18: 343-348.

Maguire, J.D. 1962. Speed of germination aid in selection and evaluation for seedling and vigour. Crop Science 2:176-177.

Nascimento, W., J. Silva, and L. Marton. 1993. Qualidade fisiológica de sementes peletizadas de tomate durante o armazenamento. Informativo ABRATES 3:47.

Levien, A., S. T. Peske, and L. Baudet. 2008. Film coating in relation to seed covering. Seed News magazine XII, n.3. Available online at: http:// www.seednews.inf.br/ingles/seed123/print_artigo123_ing.html (Website accessed on July 2012).

Pilar, M.C., Ortega, N., Perez-Mateos, M, and Busto, M.D. 2009. Alkaline phosphatase-polyresorcinol complex: characterization and application to seed coating. Journal of Agricultural and Food Chemistry 57:1967-1974.

Pilar-Izquierdo, M.C., N. Ortega, M. Perez-Mateos, and Busto, M.D. 2012. Barley seed coating with free and immobilized alkaline phosphatase to improve P uptake and plant growth. J. Agric. Sci. 150:691-701.

Scott, J.M. 1989. Seed Coatings and Treatments and their Effects on Plant Establishment. Advances in Agronomy 42: 43-83.
Silva, F.A.S., and C.A.V. Azevedo. 2009. Principal components analysis in the Software AssistatStatistical Attendance. In: World Congress on Computers in Agriculture. 7, Reno-NV-USA: American Society of Agricultural and Biological Engineers.

Silva, J.B.C., and J. Nakagawa. 1998. Confecção e avaliação de péletes de sementes de alface. Horticultura Brasileira 16:151-158.

Tavares, L.C., C.A. Rufino, C.S. Dorr, A.S.A, Barros, and S.T. Peske. 2012. Performance of lowland rice seeds coated with dolomitic limestone and aluminum silicate. Revista Brasileira de Sementes 34:202-211.

Tavares, L.C., C.A. Rufino, A.P. Brunes, F.F. Friedrich, A.C.S.A. Barros, and F.A. Villela. 2013. Physiological performance of wheat seeds coated with micronutrients. Journal of Seed Science 35:28-34.

Taylor, A.G., C.J. Eckenrode, and R.W. Straub. 2001. Seed coating technologies and treatments for onion: Challenges and progress. HortScience 36:199-205.

Zelonka, L., V. Stramkale, and M. Vikmane. 2005. Effect and after-effect of barley seed coating with phosphorus on germination, photosynthetic pigments and grain yield. Acta Univ. Latviensis 691:111-119.

Zorato, M., and A.A. Henning. 2001. Effect of fungicide seed treatment applied at different storage times on soybean seed quality. Revista Brasileira de Sementes 23:236-244. 
